\title{
NOTE ON THE TRANSLATION
}

The diaries held at the Harry Ransom Humanities Research Center at the University of Texas at Austin consist of ten slim notebooks, often bound in a handmade cover, each about the size of a school composition book. They span the years I9I4-1936 and contain Nikolay Punin's handwritten entries, newspaper clippings, and other enclosures such as a Christmas ornament made by Tatlin, postcards, and even a lock of hair (presumably Anna Akhmatova's). The diaries themselves have had some passages cut out, and others marked out at a later date. The first few notebooks contain comments written by Akhmatova in the margins. All in all, these small and somewhat battered documents are as complex and original as the man who wrote them. Even though the events that shaped his life occurred more than fifty years ago, Nikolay Punin's diaries are living testament to that life, and in reading them one is often transported back in time.

After completing a preliminary translation of the diaries, I traveled to St. Petersburg to meet the Punin family. There I found that the holdings at the HRHRC were actually the middle part of Punin's diaries and that he had kept a diary from 1904 until his death in 1953. Nikolay Punin's daughter, Irina Punina, his granddaughter, Anna Kaminskaya, and Anna's husband, Leonid Zykov, had already organized a great deal of Punin's archives into a collection of diary entries, correspondence, official documents, articles, and Akhmatova's poetry that, like a mosaic, told the story of Punin's life and work. Unfortunately, the scope of the present publication did not allow us to include all of these materials, but the family has kindly granted permission to include part of the collection dating before 1914 and after 1936 in this translation. The first section of this volume, entitled "Early Materials from the Punin Diaries, 1904-1910," and the last section, "Late Materials from the Punin Diaries, 1941-1952," are excerpts from the volume that the family is preparing for publication. We have kept their format in the translation. These sections are highly abridged; we hope that a complete volume will appear soon in Russian and eventually in English as well.

Apart from the aforementioned sections, we have also borrowed the term "Conversation Books" from Leonid Zykov's description (which he in turn borrowed from Johann Wolfgang von Goethe) of the three tiny date books included in holdings at the HRHRC. These little books 
$x$ liv

NOTE

ON THE

TRANSLATION

were Anna Akhmatova's and contain phone numbers and addresses along with short "conversations" between Akhmatova and Punin, in which Akhmatova would make an observation and Punin would answer. They signed each entry, often using nicknames for each other: Akuma or Olen for Akhmatova and K. M. or Koty for Punin.

I am greatly indebted to the Punin family for their cooperation with this project and for their warm hospitality during my stay in St. Petersburg.

Since the diaries are handwritten, there are a few passages that are illegible; these have been noted in brackets. Otherwise, I have kept to the form of the entries and any ellipses, dashes, deletion marks, and other marks are Punin's own. Editor's notes and omissions are bracketed ([. . .]). In a few cases Punin also made footnotes to his entries, which are included in the body of the text. Notes in the margin and those added at a later date are indicated in the footnotes.

Russian proper names and place names have been transliterated using the Library of Congress system, except for using $y a$ instead of $i a$, $y u$ instead of $i u, y$ instead of $i i$ or $i$, and the omission of ' to denote the presence of a soft sign (e.g., "Dostoevsky" rather than "Dostoevskii" and "Vasilevna" rather than "Vasil'evna"). In citations of Russian titles we have strictly adhered to the Library of Congress system. In those cases where a common spelling has more or less established itself, that form is used (e.g., "Tchaikovsky," not "Chaikovskii").

All items followed by an asterisk $\left(^{*}\right)$ can be found in the Glossary. 


\section{TH E}

DIARIES OF

NIKOLAY PUNIN

I 904-I953 
THIS PAGE INTENTIONALLY LEFT BLANK 


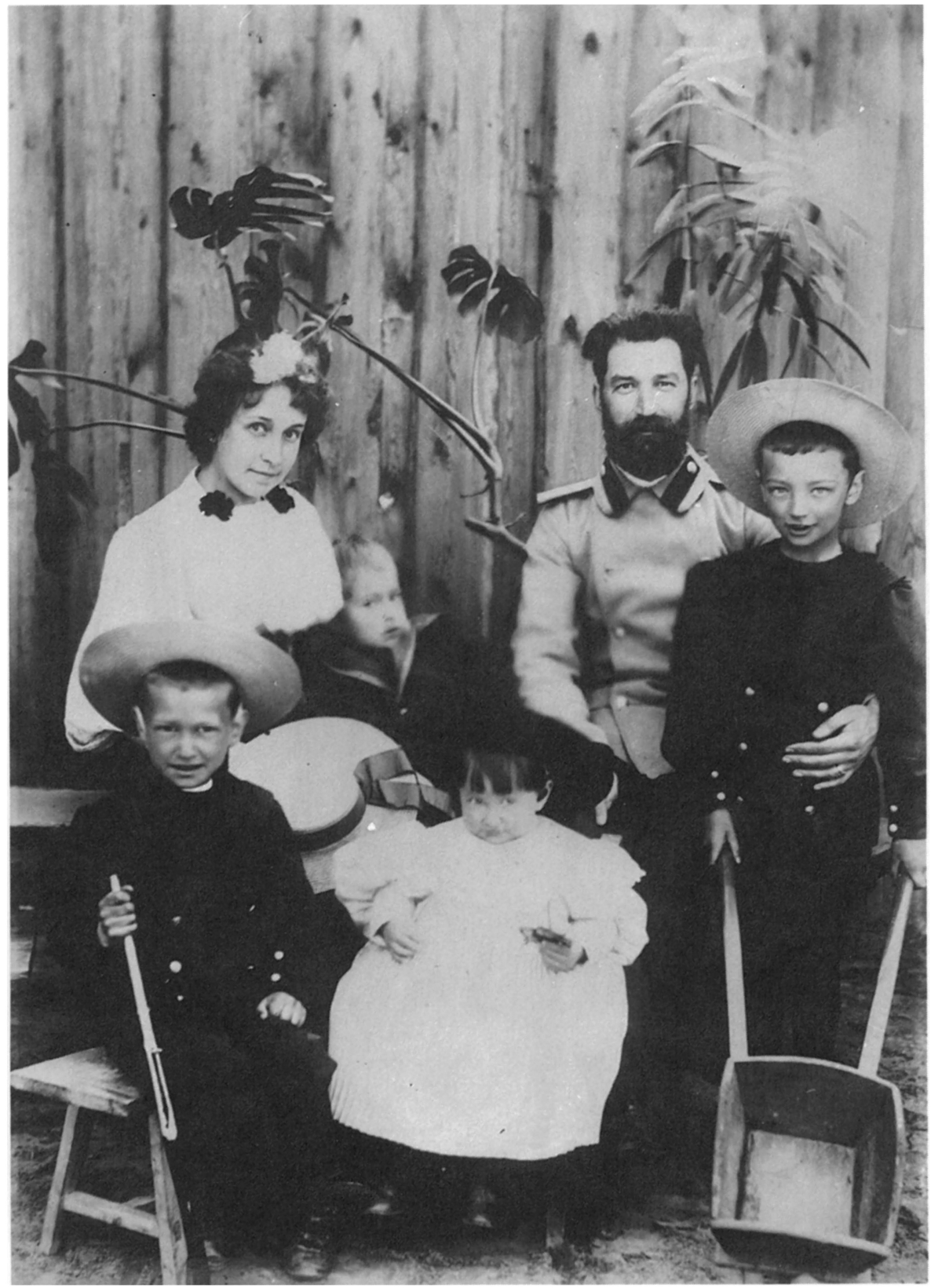

Punin family, ca. I895: left to right, Aleksandr, Punin's mother, Anna Nikolaevna, Leonid, Zina, Punin's father, Nikolay Mikhailovich, and Nikolay. courtesy of the punin family. 


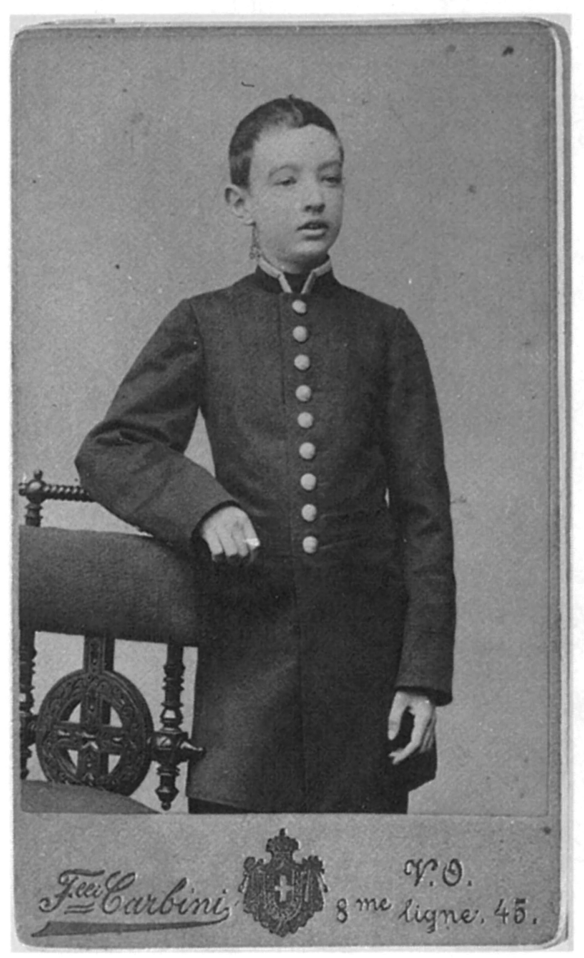

Nikolay Punin as a young student, ca. I905. COURTESY OF THE PUNIN FAMILY.

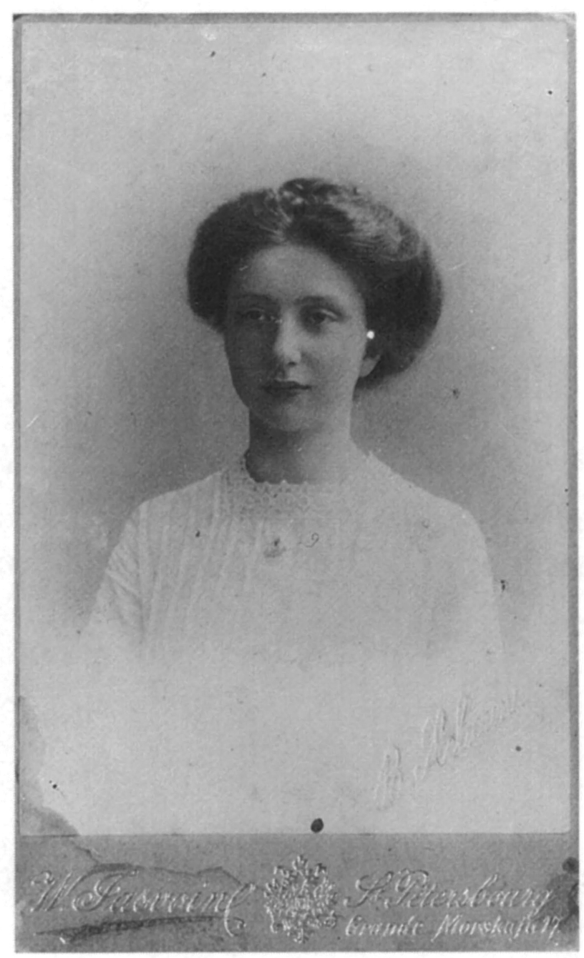

Anna (Galya) Evgenevna Ahrens, Punin's first wife, ca. I9I7. COURTESY OF THE PUNIN FAMILY. 


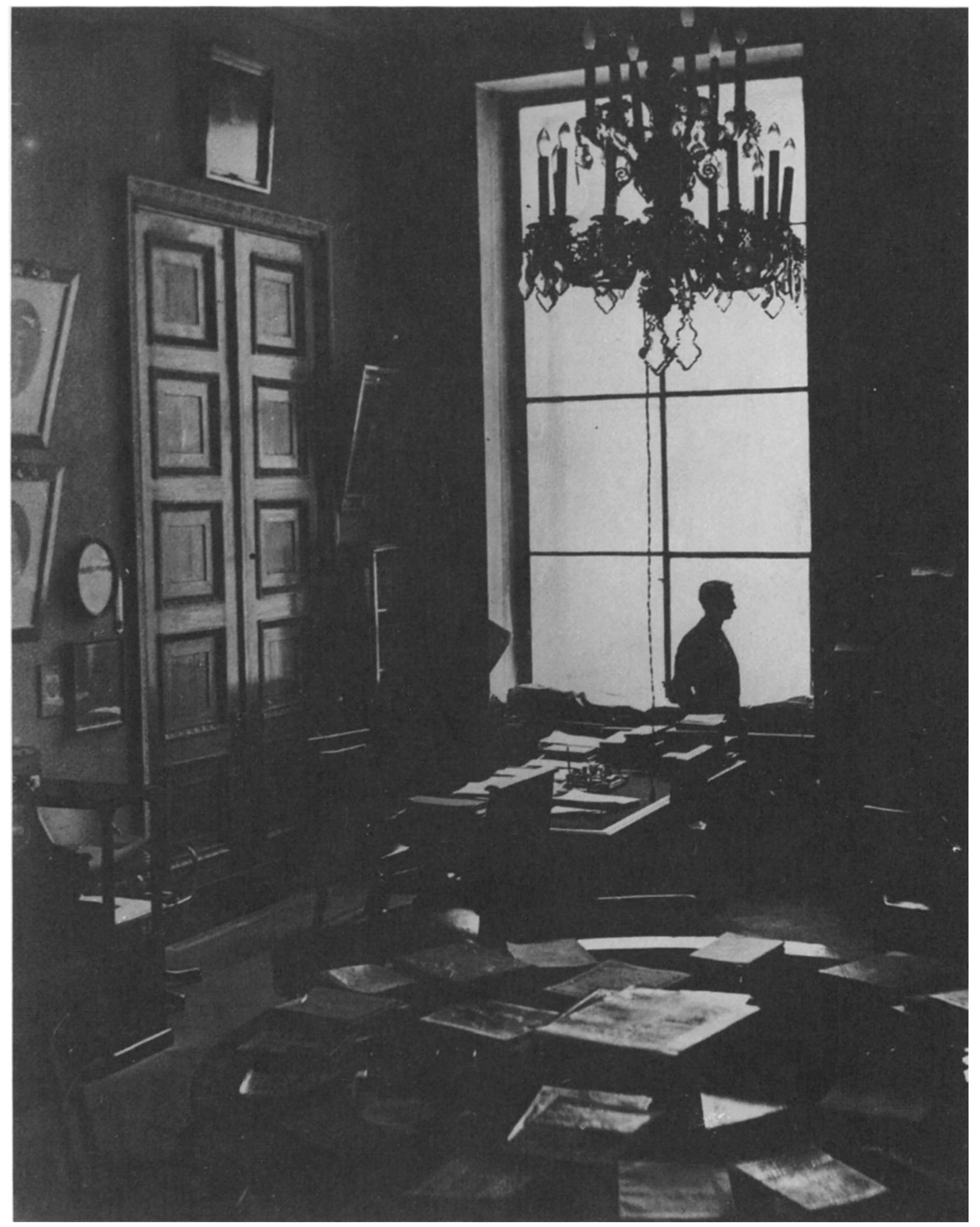

Nikolay Punin at the Russian Museum, early Ig20's. COURTESy of THE PUNin FAMILy. 


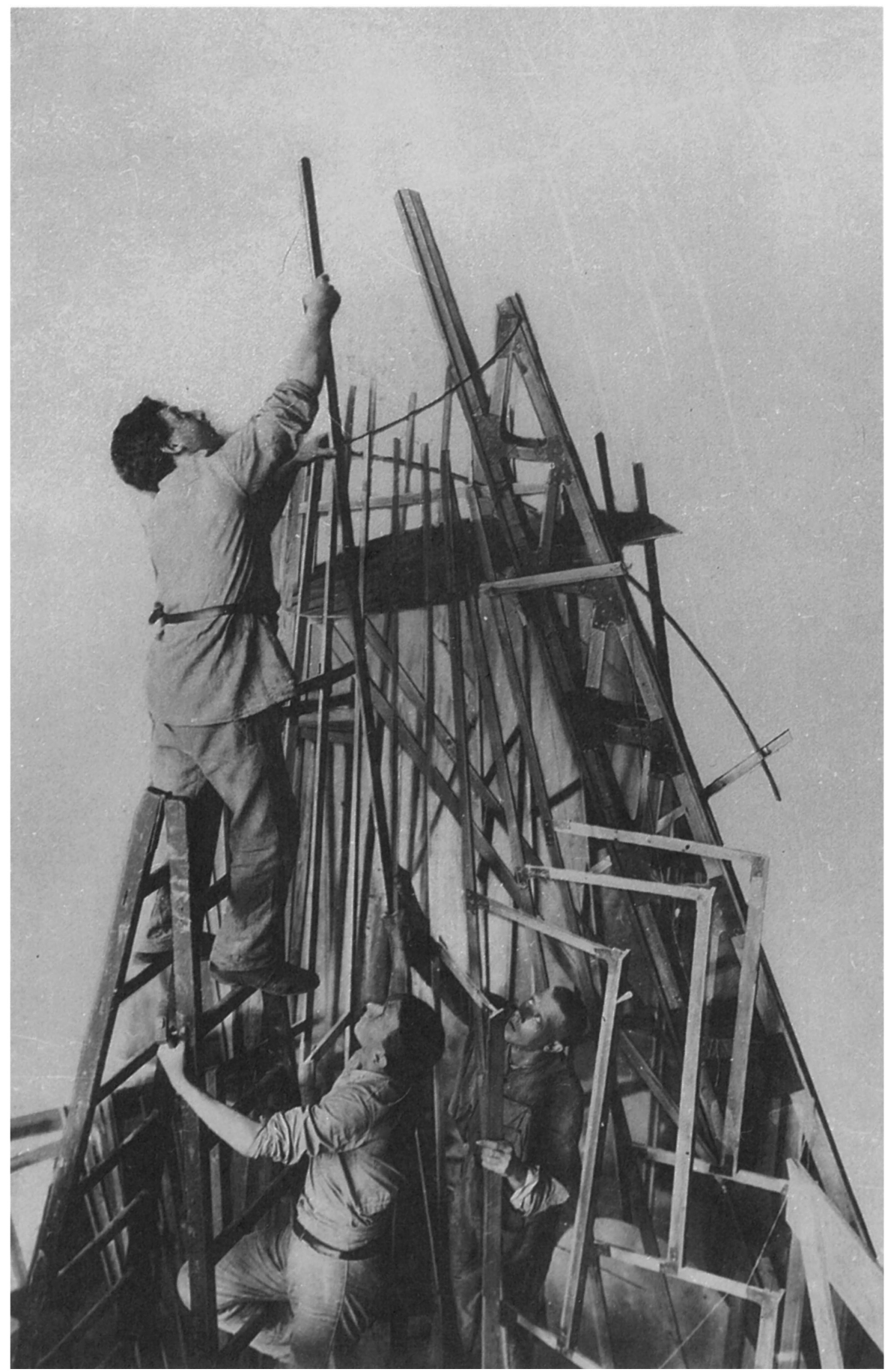

Monument to the Third International, ca. Ig20. COURTESY OF THE PUNIN FAMILY. 


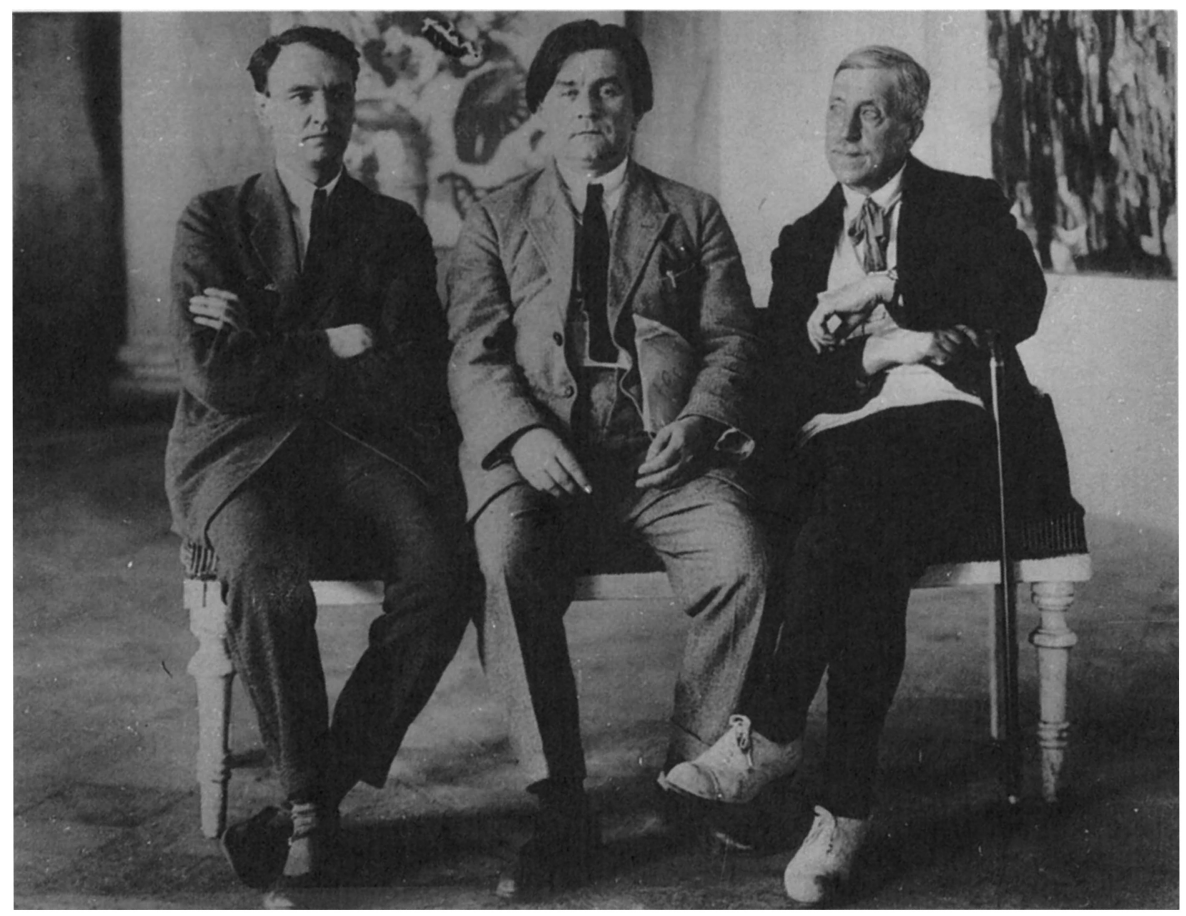

Nikolay Punin, Kazimir Malevich, and Mikhail Matyushin, I925. COURTESY OF THE PUNIN FAMILY. 


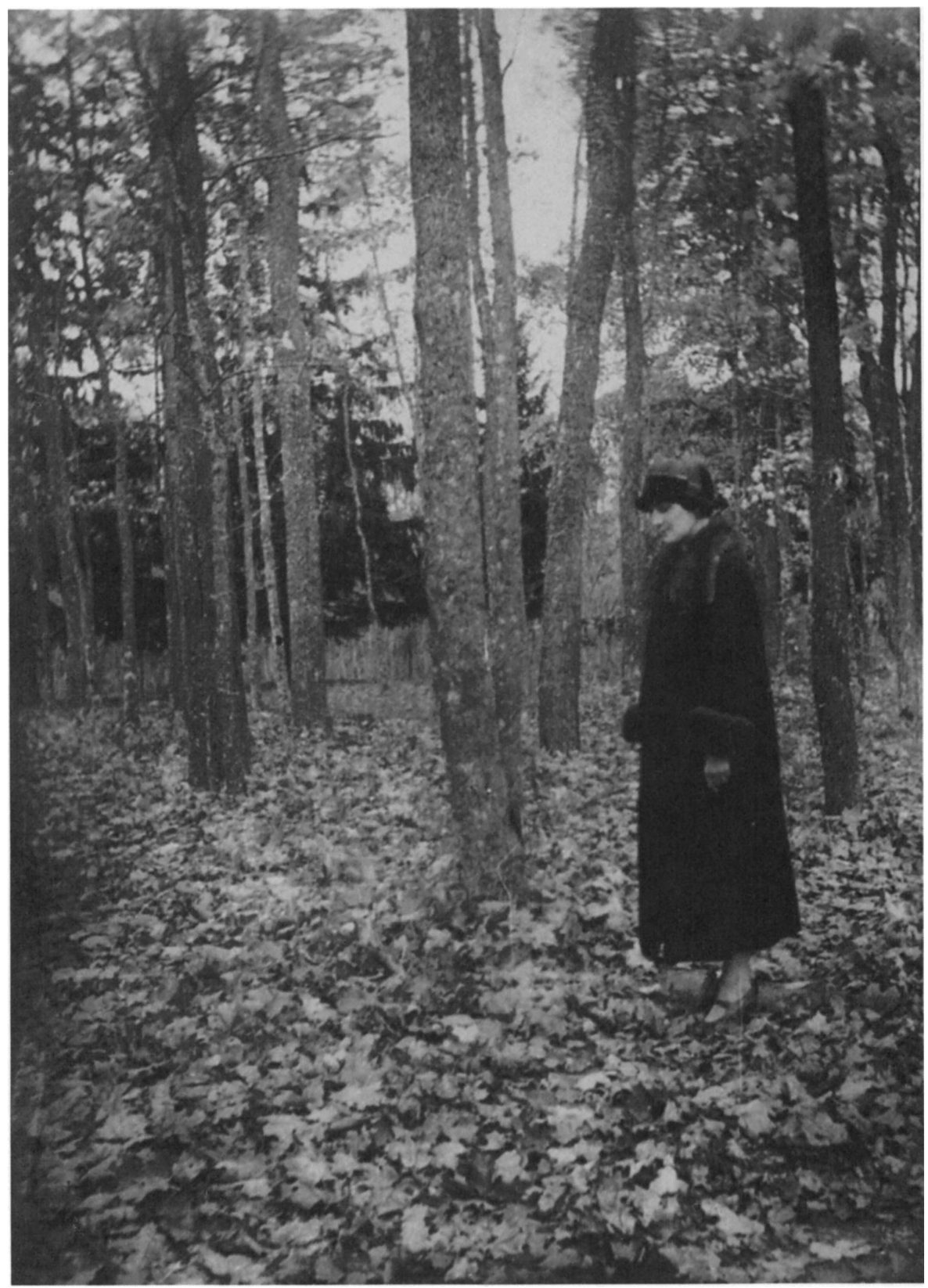

Anna Akbmatova, photo taken by Nikolay Punin, ca. 1924. Courtesy of the punin family. 


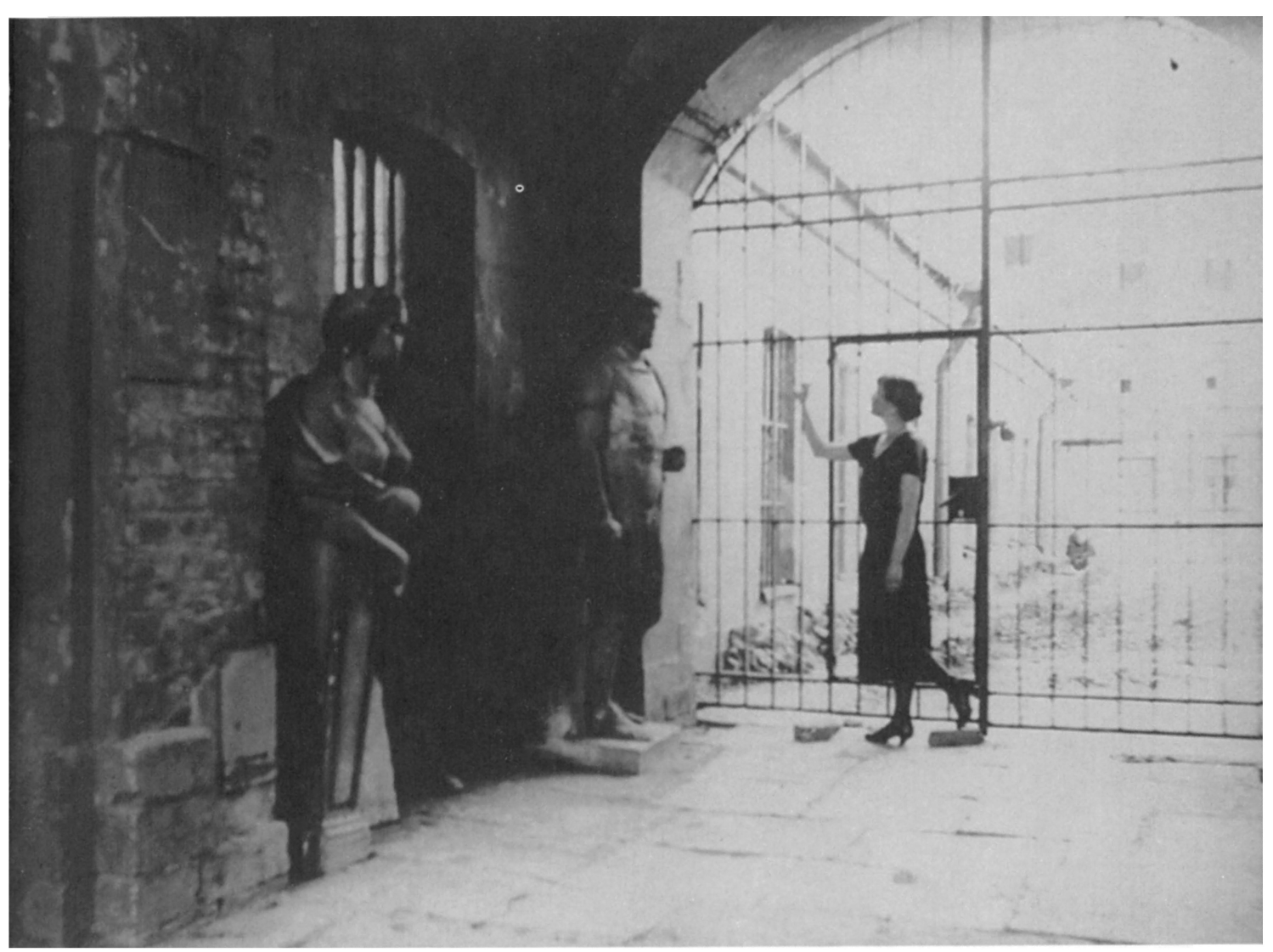

Anna Akhmatova, photo taken by Nikolay Punin, ca. 1924. Courtesy of the PUNIN family. 


\section{9 bexaspe. Mulis}

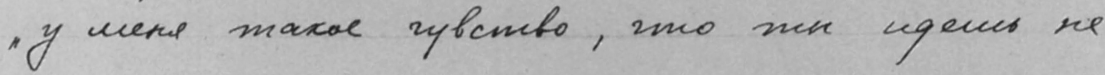

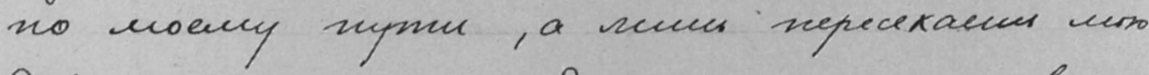

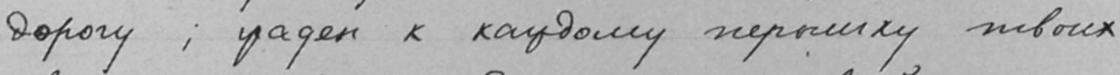
pecruay u soroes suyoenu mboü, как

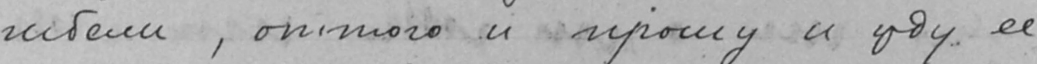
on nita ciobro cyorfy upoynpendar " ry. nuс бua

- 4

\section{Sexarper}

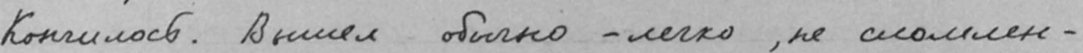

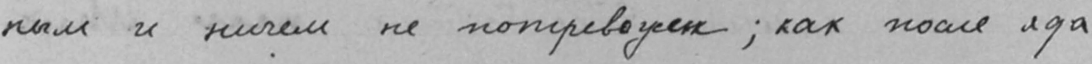
montes yсmans cepqye. Ino-ye mei maxae

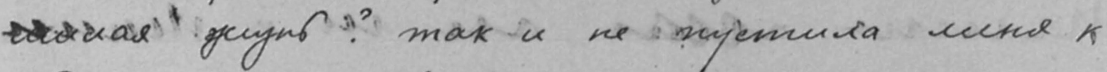

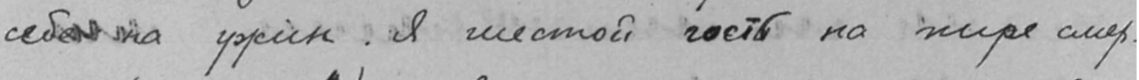

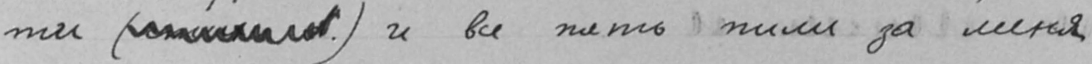
oncyniciubyrocyero, a y uence maxe rybombs,

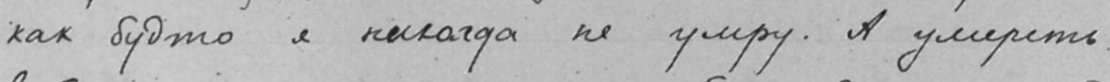

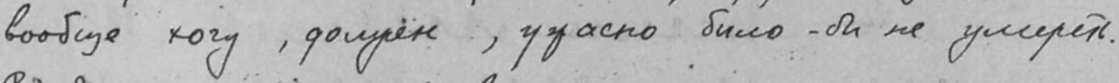
Ceraind upuizuen * An, tourgico, cuonath a nerxa

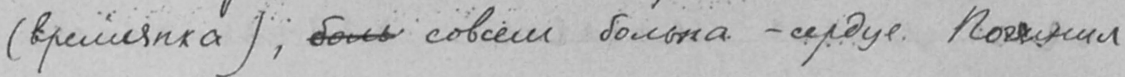

Pages from the diary. Entries for December 9 and 30, 1922.

COURTESY OF THE HARRY RANSOM HUMANITIES RESEARCH CENTER. 


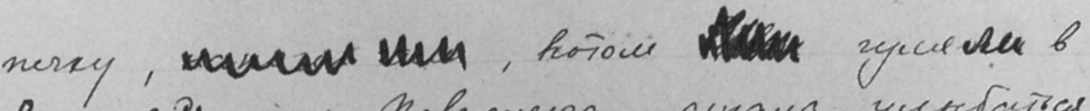
Semment cagy. Nobeceuena, cmana yuretartas

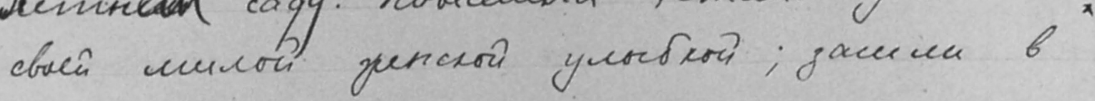

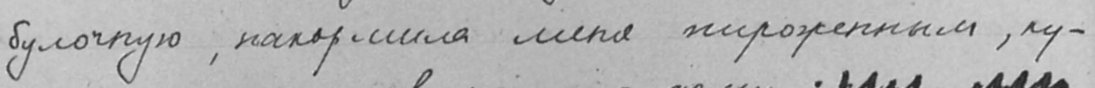

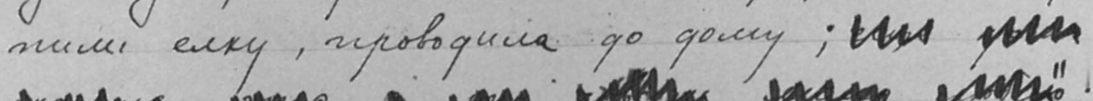

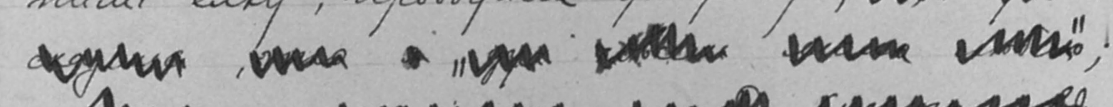

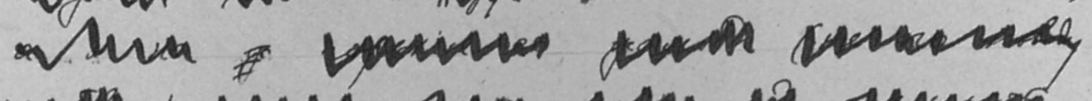

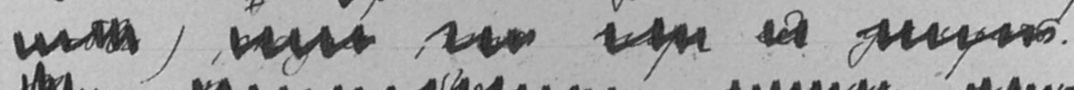

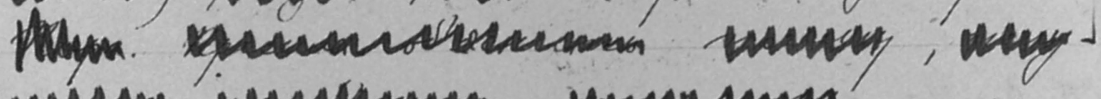

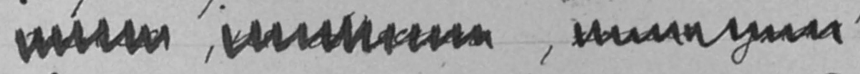

Ona japyzuena nocueque qrue decenengnes?

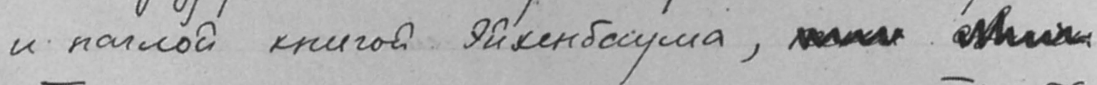

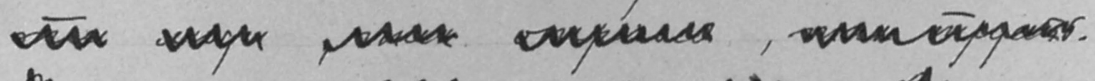

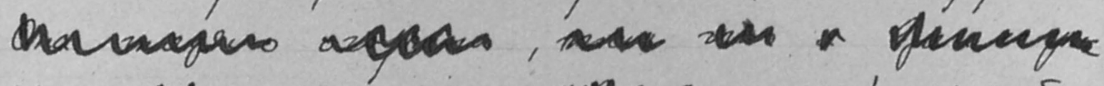

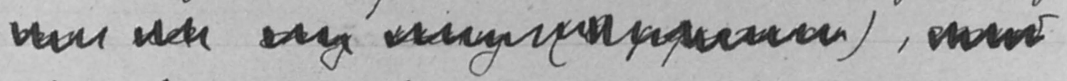
the ryour sh

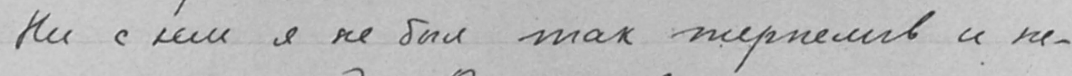

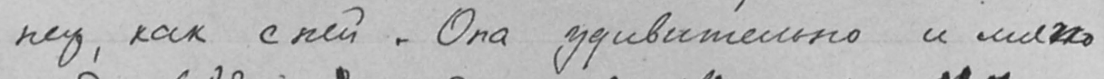

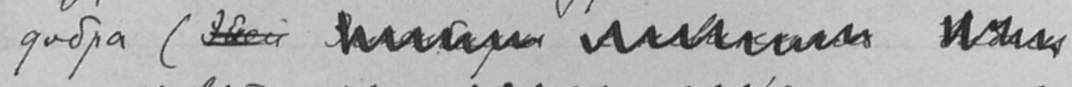

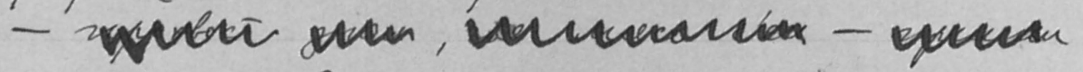

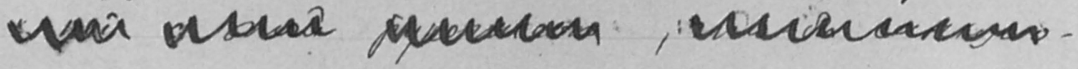




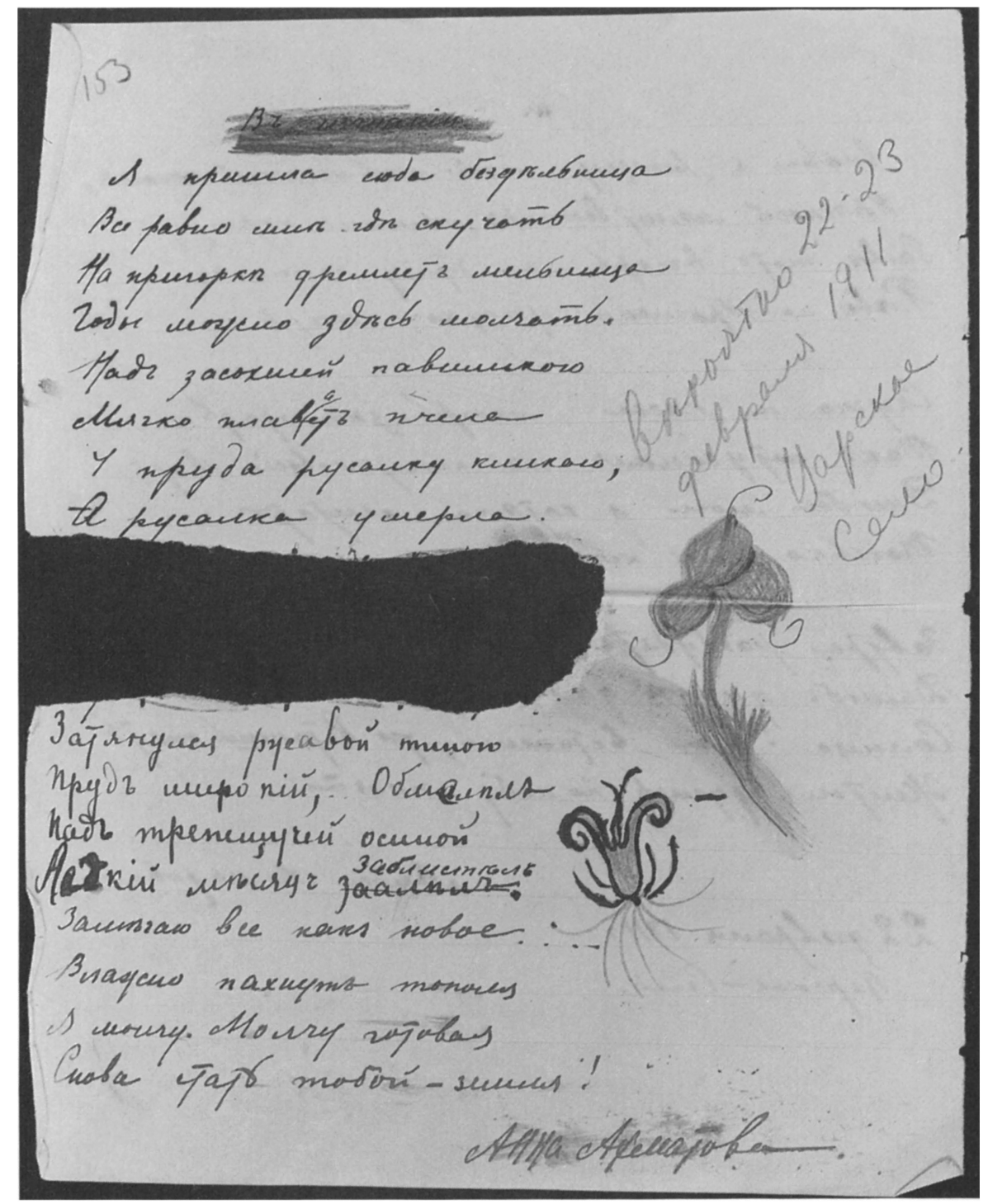

Poem in Anna Akhmatova's hand, with small drawing of a flower, n.d. COURTESY OF THE HARRY RANSOM HUMANITIES RESEARCH CENTER. 
12. Howe

An. Snura negabro ta ofque Zuroxa. Ceroques

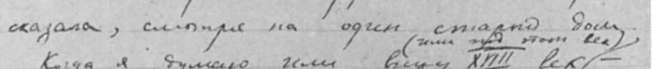

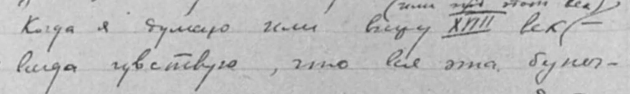

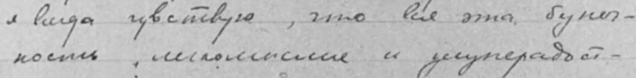

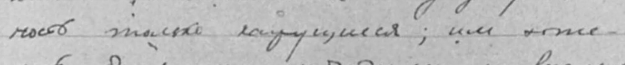

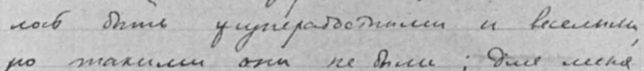

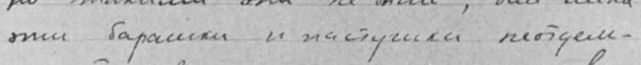
un of peborroyum, a siapuen \& faya

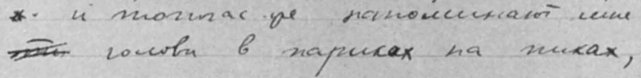
Ace mo, exyanrure ofth, ozenes Tres nee raparnupro un fobce re sceparnocmono a cuyporyyejerus, a de

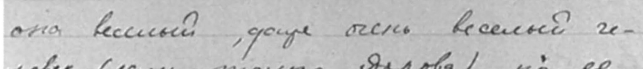
nobex (eacu moumo goproba), nò ee umpaurear zylento, sybembo m-

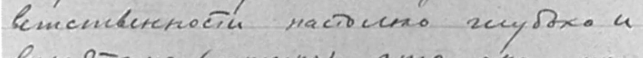
Bupabians (ceprejne, 2 mo ofra yos

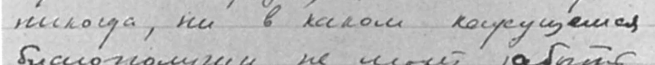

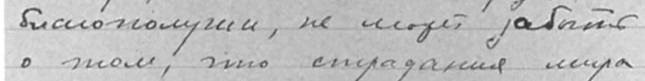

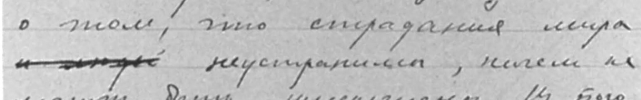

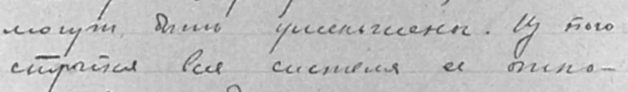

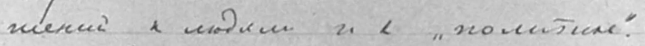
Mene barga yquebuset qo xamo dis.

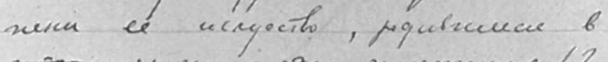

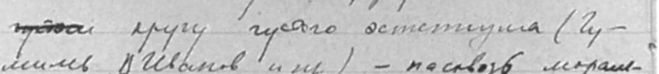

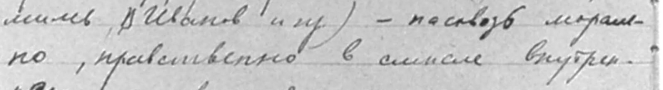
noro omargarus jeypu Cumpurs rqeimo

Pages from the diary. Entry for May I2, 1924. COURTESY OF THE HARRY RANSOM HUMANities ResearCh CENTER

Pages from Akhmatova's “Conversation Book." Entries for November 16, 1924, and December 21, 1924. COURTESY OF THE HARRY RANSOM HUMANITIES RESEARCH CENTER.

U. 2en. 24,

Mpam. Db.

despy Joubnox, a Rul. npuluer co une c leqposes. dewobow. Gcasau, rmo he nonunaro, $2 \bar{m} 0$ Taree Dusurusisu" Booveye nomperan cepoetro. Perumea $a$ atolel. Epocurt.

tax. lagnto ivenuna mar
16 Октябрь.

Horosespes. 24.

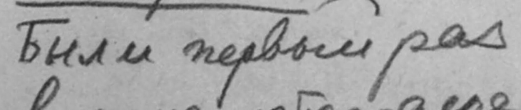
l. sureinatioyaye.

Spppente.

vent 

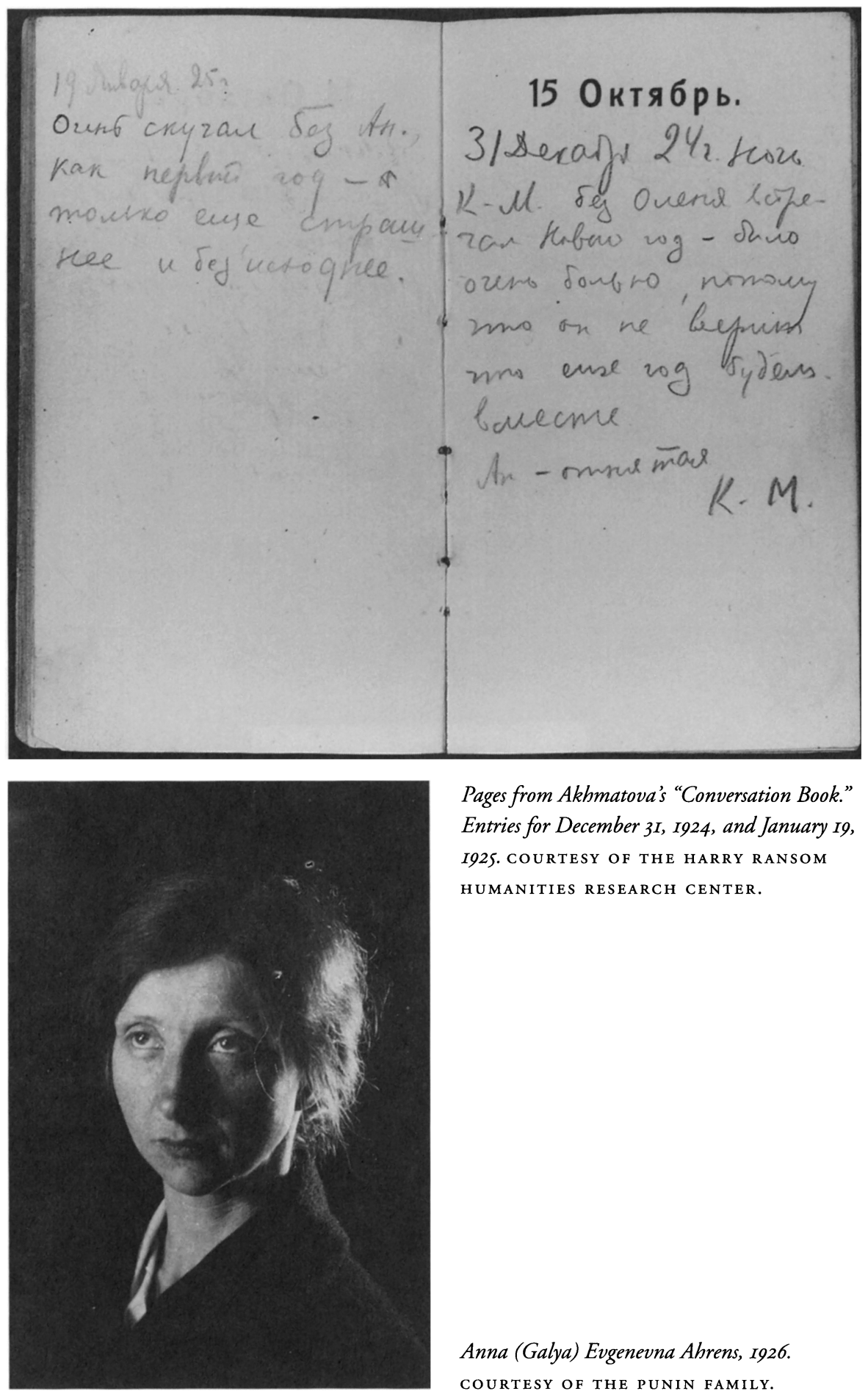

Pages from Akhmatova's "Conversation Book." Entries for December 3I, I924, and January I9, I925. COURTESY OF THE HARRY RANSOM HUMANITIES RESEARCH CENTER.

Anna (Galya) Evgenevna Abrens, 1926. COURTESY OF THE PUNIN FAMILY. 


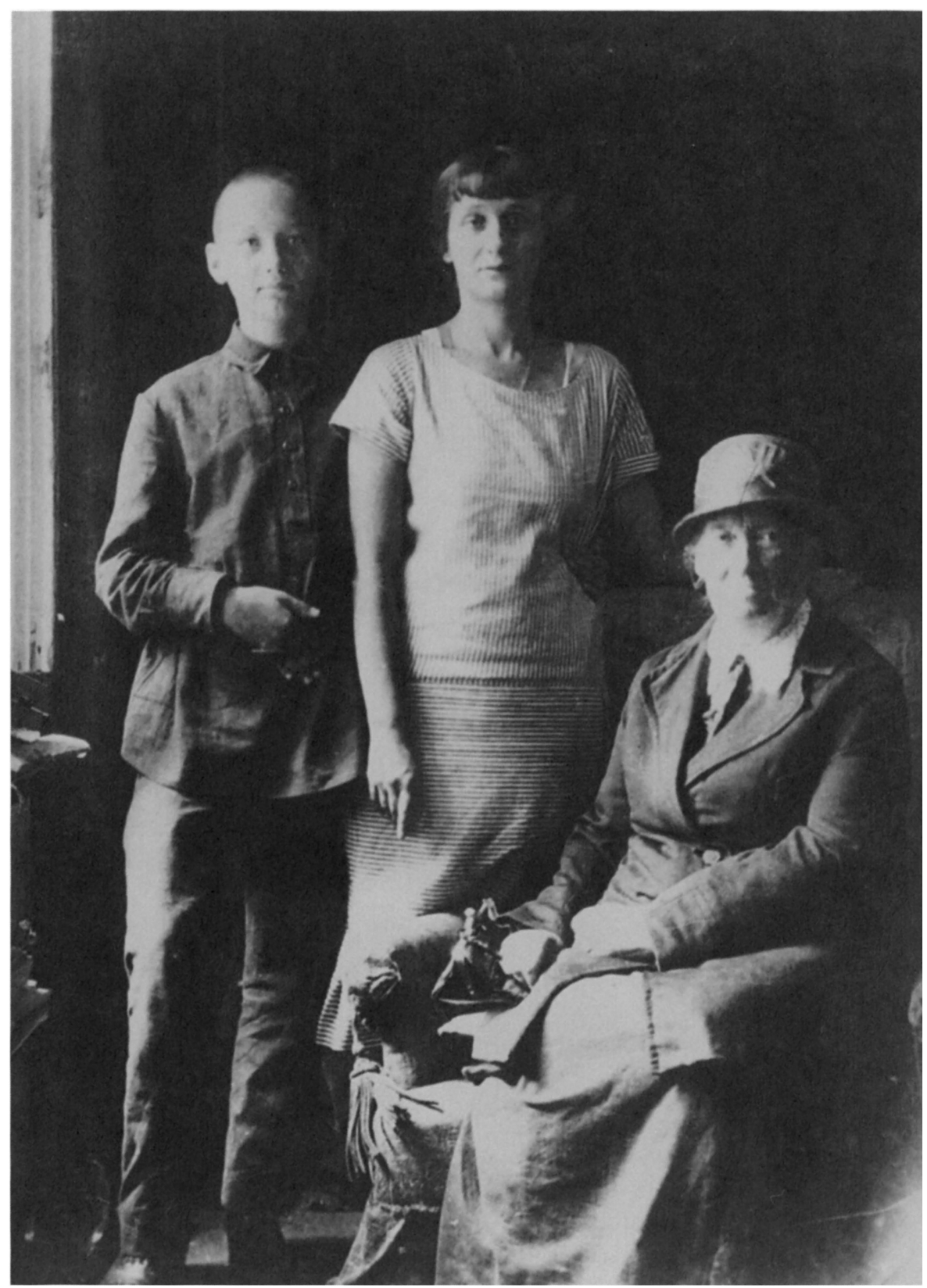

Anna Akhmatova with her son Lev and mother-in-law, Anna Ivanovna Gumileva, rg27. COURTESY OF THE PUNIN FAMILY. 


\section{C C P}

Народный Номиссариат Внутренних Дел

Управленке нКвд no

Ленинградской Области дом

ПРЕДВАРИТЕЛЬН. ЗАКЛЮЧ. 2. $\frac{x i}{x-1935} \mathrm{r}$

Ленивград, ул. Воинова, 25.

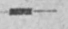

зак. $797-10000$.

\section{Удостоверение}

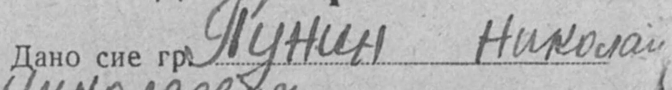
Alwanaebar B TOM, чTO OH. содержалі\& в Доме Предварительного

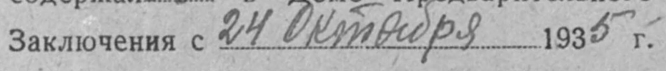
и согласно ордера уНКВД СССР по ЛО от 3.40 . $193 b^{5}$ за №1048.73 4ал-пол ареста освобожден $31 \times 13$ s.

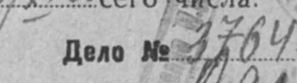

Photo of Nikolay Punin's document of release from prison, 1935. COURTESY OF THE HARRY RANSOM HUMANITIES RESEARCH CENTER.

Anna Akhmatova with Anna Kaminskaya, 1946. courtesy of the punin family.

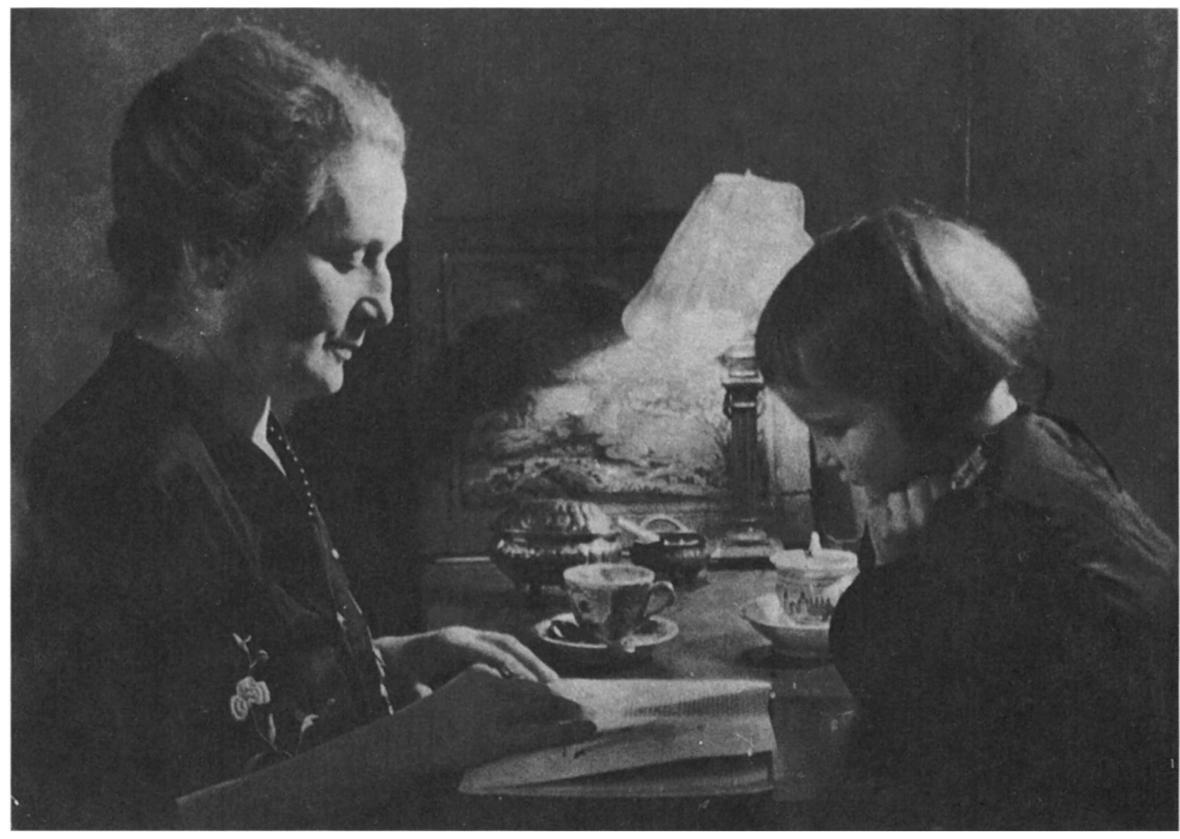




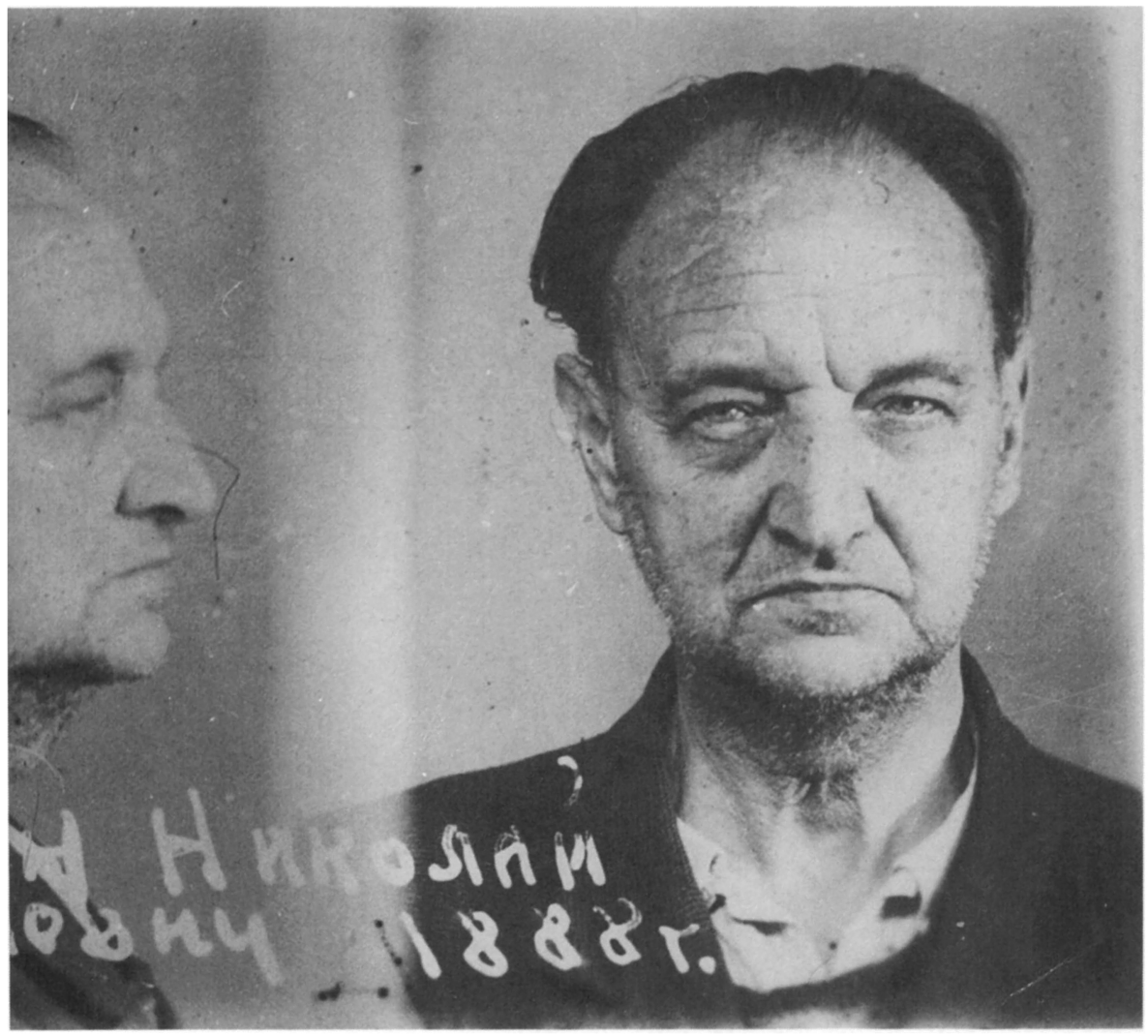

Nikolay Punin after final arrest in I949. COURTESY OF THE PUNIN FAMILY. 
THIS PAGE INTENTIONALLY LEFT BLANK 